\title{
Hubungan Pola Asuh Orang Tua dengan Psychological Self Concept Anak Dalam Kegiatan Pembelajaran di Sekolah Dasar
}

\author{
Tarmidzi \\ Fakultas Keguruan dan Ilmu Pendidikan, Universitas Swadaya Gunung Jati \\ Mulyatarmidzi@gmail.com
}

\begin{abstract}
Abstrak
Penelitian ini bertujuan untuk mengukur hubungan pola asuh orang tua terhadap psychological self concept anak usia sekolah dasar serta menganalisis psychological self concept anak usia sekolah dasar sesuai tipe pola asuh orang tuanya. Dalam penelitian ini penulis menggunakan metode Penelitian Ex Post Facto.Sampel pada penelitian ini adalah 30 orang tua dan siswa SD Negeri 2 Kemantren Kabupaten Cirebon. Berdasarkan hasil uji korelasi Pearson Product Moment $\left(\mathrm{r}_{\mathrm{ppm}}\right)$ didapatkan nilai korelasi $\mathrm{r}=0,301$ dengan interpretasi hubungan yang rendah antara pola asuh orang tua dengan psychological self concept siswa. Sedangkan $P$-Value yang didapat $=0,106(P$-Value $>0,01)$ sehingga dapat disimpulkan bahwa tidak terdapat hubungan yang signifikan antara pola asuh orang tua dengan psychological self concept siswa. Meskipun terdapat orang tua yang memiliki pola asuh otoriter, tetapi psychological self concept anaknya tetap dalam interpretasi baik.
\end{abstract}

Kata kunci : $\quad$ Pola Asuh Orang Tua;Psychological Self Concept

\section{PENDAHULUAN}

Latar Belakang Masalah. Masa anak adalah masa perkembangan yang cepat yang ditandai dengan perubahan dalam banyak aspek perkembangan. Pengalaman saat masa anak akan sangat berpengaruh terhadap perkembangan selanjutnya. Pendidikan pada masa sekolah dasar merupakan salah satu pondasi bagi pendidikan anak untuk jenjang selanjutnya, apabila anak mendapat perlakuan yang baik selama masa kanak-kanak hingga sekolah dasar, maka proses perkembangan dan pendidikan anak dapat diharapkan mengalami perkembangan yang optimal. Ada beberapa faktor yang mempengaruhi perkembangan anak, diantaranya adalah faktor keturunan (hereditas) dan lingkungan perkembangan (Yusuf, 2006 : 31). Lingkungan merupakan segala sesuatu yang berada di luar individu yang meliputi fisik dan sosialnya (Kathena, 1992 : 58; Yusuf, 2006 : 35). Lingkungan perkembangan siswa meliputi lingkungan keluarga, sekolah, teman sebaya, dan masyarakat.Lingkungan keluarga merupakan lingkungan yang pertama kali mengenalkan banyak hal pada anak. Menurut Yusuf (2006: 38), secara psikososiologis keluarga memiliki beberapa fungsi, diantaranya adalah (1) pemberi rasa aman bagi anak dan anggota keluarga lainnya, (2) sumber pemenuhan kebutuhan baik fisik maupun psikis, (3) sumber kasih sayang dan penerimaan, (4) model pola perilaku yang tepat bagi anak untuk belajar menjadi anggota masyarakat yang baik, (5) pemberi bimbingan bagi pengembangan perilaku yang secara sosial dianggap tepat, (6) pembentuk anak dalam memecahkan masalah yang dihadapinya dalam rangka menyesuaikan dirinya terhadap kehidupan, (7) pemberi bimbingan dalam belajar keterampilan motorik, verbal dan sosial yang dibutuhkan untuk penyesuaian diri, (8) stimulator bagi pengembangan kemampuan anak untuk mencapai prestasi, baik di sekolah maupun di masyarakat, (9) pembimbing dalam mengembangkan aspirasi, dan (10) sumber persahabatan/teman bermain bagi anak sampai cukup usia untuk mendapatkan teman di luar rumah, atau apabila persahabatan di luar rumah tidak memungkinkan. Perkembangan anak sangat dipengaruhi oleh proses perlakuan atau bimbingan orang tua 
terhadap anak dalam mengenalkan berbagai aspek kehidupan sosial, atau norma-norma kehidupan bermasyarakat serta mendorong dan memberikan contoh kepada anaknya bagaimana menerapkan norma-norma tersebut dalam kehidupan sehari-hari (Yusuf LN, 2006: 122). Baumrind pada tahun 1991 (Santrock, 2002: 257) menyatakan bahwa orang tua tidak boleh menghukum atau mengucilkan, tetapi sebagai gantinya orang tua harus mengembangkan aturan-aturan bagi anak dan mencurahkan kasih sayang kepada mereka. Baumrind (1991) juga menekankan tiga tipe pengasuhan yang dikaitkan dengan aspek yang berbeda dalam perilaku anak, yaitu Autoritarian (otoriter), Autoritative (otoritatif), Indulgent (terlalu baik) dan Uninvolved (tidak terlibat).Berdasarkan hasil observasi di lingkungan rumah, penulis menemukan anak dengan sifat yang kurang memiliki konsep diri yang baik, susah dalam mengambil keputusan, mudah putus asa dan sering menyikapi sesuatu secara negatif, setelah penulis mencari tahu, ternyata orang tua anak tersebut dalam mendidik anaknya di rumah bersikap otoriter, apapun yang orang tua inginkan harus dipenuhi tanpa mau mendengar keluhan atau pendapat anak, sering melakukan hukuman fisik dan verbal kepada anak, serta suka menghina anak apabila anak melakukan kesalahan. Pada kasus lain penulis menemukan anak dengan sifat periang, percaya diri, optimis serta mudah membangun komunikasi dengan orang lain. Pola asuh orang tua anak tersebut apabila anak salah maka ditegur tanpa menyakiti perasaan anak, apabila anak berhasil melakukan sesuatu dengan baik, anak tersebut akan mendapat pujian dan diberi kasih sayang lebih, selain itu orang tua tersebut selalu mendukung bakat dan minat anak. Penulis melihat dan merasakan betapa pola asuh orang tua berhubungan dengan perkembangan konsep diri anak.Anak seperti tanah liat yang mudah dibentuk oleh orang tuanya. Bagaimana bentuk anak nanti akan tergantung dari orang tuanya, Mereka tumbuh sebagaimana pola asuh orang tuanya yang berbeda-beda. Berdasarkan latar belakang di atas, artikel ini akan membahas terkait pola asuh orang tua dan hubungannya dengan psychological self concept anak dalam kegiatan pembelajaran di sekolah dasar dengan rumusan masalah sebagai berikut.

Pola Asuh Orang Tua.Anak adalah amanah dari Allah swt.yang harus dirawat, dijaga, dibesarkan, dan dididik dengan sebaik-baiknya karena setiap orang tua yang dikaruniai anak akan diminta pertanggungjawabannya kelak oleh Allah swt, Peran orang tua sangat penting dalam tumbuh kembang anak. Bagaimana fisik, sifat dan kepribadian, konsep diri, inteligensi, sosial, serta emosional anak tergantung dari orang tuanya.Bukhari meriwayatkan sebuah hadits yang menyatakan bahwa,"setiap anak yang dilahirkan adalah fitrah (suci), tinggal kedua orang tuanyalah yang akan menjadikannya sebagai seorang Yahudi, Nasrani, ataupun Majusi”.Hadits tersebut menggambarkan secara jelas peran vital orang tua dalam tumbuh kembang anak baik secara fisik, intelektual, emosional, mental dan spiritual.Selain peran dan pola asuh orang tua, perkembangan anak sendiri dipengaruhi oleh hal-hal lain, diantaranya faktor keturunan, dan lingkungan.Pola asuh orang tua merupakan salah satu faktor yang cukup menentukan dalam tumbuh kembang anak.Menurut Baumrind (1991), pola asuh orang tua dapat dibedakan menjadi 4 tipe, yaitu:

a. Autoritative (Demokratis) yang memiliki ciri :

i. hubungan dua arah (orang tua anak);

ii. mau mendengarkan pendapat anak;

iii. komunikasi terjalin baik;

iv. pengasuhan berpusat pada anak.

b. Autoritarian (Otoriter) yang memiliki ciri:

i. orang tua berfungsi sebagai pengontrol anak;

ii. kekuasaan tegas;

iii. hubungan (orang tua - anak) tidak terjalin dua arah; 
iv. masih terdapat komunikasi.

c. Indulgent (Terlalu baik) yang memiliki ciri:

i. terlalu baik;

ii. tidak menuntut;

iii. tidak mengontrol;

iv. serba membolehkan.

d. Uninvolved (Tidak terlibat) yang memiliki ciri:

i. tidak menuntut;

ii. tidak mengontrol;

iii. menolak pendapat anak;

iv. tidak mau mendengarkan.

Jadi, pada tipe pola asuh Autoritative, fungsi pengawasan orang tua cukup baik dan kehangatan keluarga juga cukup baik, pada tipe Autoritarian fungsi pengawasan/kontrol tinggi tetapi kehangatan kurang sehingga orang tua lebih sering menuntut anaknya. Pada tipe pola asuh Indulgent fungsi pengawasan/kontrol lemah tetapi kehangatan tinggi sehingga anak cenderung dimanja, sedangkan pada tipe Uninvolved fungsi pengawasan/kontrol lemah sehingga orang tua terkesan tidak perduli terhadap anaknya.

Psychological Self Concept.Prestasi belajar anak di sekolah salah satunya dapat diukur/dilihat dari konsep diri anak secara psikologis. Konsep diri akan mempengaruhi perilaku anak baik dalam pergaulan seharihari (kegiatan sosial) maupun dalam kegiatan pembelajaran. Dalam kegiatan pembelajaran, konsep diri anak yang positif akan membantu anak agar lebih mandiri dan percaya diri dalam belajar sehingga diharapkan anak dapat mencapai prestasi belajar yang optimal.Konsep diri adalah gagasan mengenai dirinya sendiri meliputi keyakinan, pandangan dan penilaian seseorang terhadap dirinya sendiri (Desmita, 2012: 164). Konsep diri, masih menurut Desmita terdiri atas bagaimana cara kita merasa tentang diri sendiri, bagaimana kita menginginkan diri sendiri menjadi manusia sebagaimana yang kita harapkan, dan bagaimana cara kita melihat diri sendiri sebagai pribadi.Menurut Hurlock (Yusuf \& Nurikhsan, 2011: 7), gambaran dari self concept meliputi fisik, psikologis, sosial, emosional, aspirasi dan prestasi yang telah dicapainya.segi fisik meliputi penampilan fisik, daya tarik dan penampilan. Segi psikologis meliputi pemikiran, perasaan, kemandirian, kepercayaan, penyesuaian, keberanian, kejujuran serta aspirasi. Sarwono (Musriadi, 2013: 15 ; Silviyani, 2015 : 14) mendefinisikan self concept sebagai perseptual total individu tentang dirinya sendiri secara fisik, sosial dan intelektual. Self concept dapat bernilai positif dan negatif.Individu yang memiliki konsep diri positif memiliki ciri-ciri sebagai berikut.

1. Mampu mengatasi masalahnya sendiri.

2. Merasa memiliki posisi yang sama dengan orang lain.

3. Menerima pujian tanpa ada rasa malu.

4. Menyadari bahwa tiap individu memiliki bermacam perasaan dan keinginan yang tidak selalu diterima oleh masyarakat luas.

5. Mampu memperbaiki diri dan kepribadiannya.

Yusuf dan Nurikhsan (2011: 7) membagi self concept ke dalam tiga komponen sebagai berikut.

1. Perceptual atau physical self concept, yaitu citra seseorang tentang penampilan dirinya (kemenarikan tubuhnya), seperti: kecantikan, keindahan, atau kemolekan tubuhnya.

2. Conceptual atau psychological self concept, yaitu konsep seseorang tentang kemampuan (keunggulan) dan ketidakmampuan (kelemahan) dirinya, dan masa depannya, serta meliputi juga kualitas penyesuaian hidupnya: honesty, self confidence, independence, dan courage.

3. Attitudinal, yang menyangkut perasaan seseorang tentang dirinya, sikapnya terhadap keberadaan dirinya sekarang dan masa depannya, sikapnya terhadap keberhargaan, kebanggaan, dan keterhinaannya.

Berdasarkan latar belakang di atas, maka rumusan masalah dalam penelitian ini dapat dituliskan sebagai berikut. 
1. Apakah terdapat hubungan antara pola asuh orang tua terhadap psychological self concept anak dalam kegiatan pembelajaran di sekolah dasar?

2. Bagaimanakah psychological self concept anak usia sekolah dasar sesuai tipe pola asuh orang tua?

Dalam Penelitian ini setiap anak akan mengisi angket berisi pernyataan-pernyataan seputar pola asuh orang tuanya kemudian jawaban siswa dianalisis baik secara kuantitatif maupun kualitatif untuk

\section{METODE}

Dalam penelitian ini penulis menggunakan metode Penelitian Ex Post Facto. Sampel penelitian sebanyak 30 orang tua serta siswa salah satu SD di Kabupaten Cirebon.

\section{HASIL DAN PEMBAHASAN}

Data pola asuh orang tua siswa SD Negeri 2 Kemantren berisi 15 pernyataan dengan opsi jawaban berupa pilihan ganda. Pilihan A menggambarkan pola asuh Tipe Autoritative dan akan diberi poin 4, pilihan B menggambarkan pola asuh Tipe Autoritarian (otoriter) dan akan diberi poin 3, pilihan $\mathrm{C}$ mendapatkan gambaran psychological self concept masing-masing anak disesuaikan dengan pola asuh orang tuanya serta mengukur hubungan pola asuh orang tua dengan psychological self concept anak itu sendiri. Penelitian ini bertujuan untuk mengidentifikasi hubungan pola asuh orang tua dengan psychological self concept anak usia sekolah dasar serta menganalisis psychological self concept anak usia sekolah dasar sesuai tipe pola asuh orang tuanya.

Instrumen penelitian ini adalah lembar angket pola asuh orang tua dengan pilihan ganda dan lembar angket psychological self concept siswa menggunakan skala Likert.

menggambarkan pola asuh Tipe Indulgent (memanjakan) dan akan diberi poin 2, sedangkan pilihan $\mathrm{C}$ menggambarkan pola asuh Tipe Uninvolved (tidak terlibat) dan akan diberi poin 1 . Pemberian poin ini hanya untuk memudahkan dalam analisis data. Nilai hasil angket pola asuh orang tua dapat dilihat pada Tabel 1 berikut. 
Tabel 1. Data Nilai Pola Asuh Orang Tua

\begin{tabular}{|c|c|c|c|c|c|c|}
\hline \multirow{2}{*}{ Subjek } & \multirow{2}{*}{ Nilai } & \multicolumn{4}{|c|}{ Pilihan Jawaban } & \multirow{2}{*}{$\begin{array}{c}\text { Rata- } \\
\text { rata }\end{array}$} \\
\hline & & 4 & 3 & 2 & 1 & \\
\hline S-1 & 54 & 11 & 2 & 2 & 0 & 3.60 \\
\hline S-2 & 53 & 11 & 2 & 1 & 1 & 3.53 \\
\hline S-3 & 54 & 11 & 2 & 2 & 0 & 3.60 \\
\hline S-4 & 49 & 7 & 6 & 1 & 1 & 3.27 \\
\hline S-5 & 51 & 11 & 0 & 3 & 1 & 3.40 \\
\hline S-6 & 53 & 11 & 2 & 1 & 1 & 3.53 \\
\hline S-7 & 52 & 8 & 6 & 1 & 0 & 3.47 \\
\hline S-8 & 57 & 13 & 1 & 1 & 0 & 3.80 \\
\hline S-9 & 55 & 12 & 1 & 2 & 0 & 3.67 \\
\hline S-10 & 56 & 12 & 2 & 1 & 0 & 3.73 \\
\hline S-11 & 51 & 7 & 7 & 1 & 0 & 3.40 \\
\hline S-12 & 48 & 8 & 3 & 3 & 1 & 3.20 \\
\hline S-13 & 50 & 9 & 3 & 2 & 1 & 3.33 \\
\hline S-14 & 48 & 9 & 2 & 2 & 2 & 3.20 \\
\hline S-15 & 53 & 9 & 5 & 1 & 0 & 3.53 \\
\hline S-16 & 52 & 8 & 6 & 1 & 0 & 3.47 \\
\hline S-17 & 37 & 5 & 1 & 5 & 4 & 2.47 \\
\hline S-18 & 51 & 9 & 4 & 1 & 1 & 3.40 \\
\hline S-19 & 47 & 5 & 8 & 1 & 1 & 3.13 \\
\hline S-20 & 49 & 8 & 3 & 4 & 0 & 3.27 \\
\hline S-21 & 52 & 8 & 6 & 1 & 0 & 3.47 \\
\hline S-22 & 49 & 6 & 7 & 2 & 0 & 3.27 \\
\hline S-23 & 59 & 14 & 1 & 0 & 0 & 3.93 \\
\hline S-24 & 58 & 13 & 2 & 0 & 0 & 3.87 \\
\hline S-25 & 59 & 14 & 1 & 0 & 0 & 3.93 \\
\hline S-26 & 59 & 14 & 1 & 0 & 0 & 3.93 \\
\hline S-27 & 51 & 9 & 3 & 3 & 0 & 3.40 \\
\hline
\end{tabular}


JURNAL ILMIAH ILMU PENDIDIKAN DASAR G

\begin{tabular}{|c|c|c|c|c|c|r|}
$\mathbf{S - 2 8}$ & 50 & 8 & 4 & 3 & 0 & $\mathbf{3 . 3 3}$ \\
\hline $\mathbf{S - 2 9}$ & 56 & 13 & 0 & 2 & 0 & $\mathbf{3 . 7 3}$ \\
\hline $\mathbf{S - 3 0}$ & 47 & 7 & 5 & 1 & 1 & $\mathbf{3 . 1 3}$ \\
\hline Rerata & $\mathbf{5 2}$ & \multicolumn{4}{|l}{} \\
\hline Deviasi & 4.57 & &
\end{tabular}

Sumber: Data Penelitian

\section{Data psychological self concept siswa}

Data psychological self concept siswa terdiri atas 19 pernyataan menggunakan skala Likert dengan pilihan jawaban SS, S, TS, dan STS. Pada pernyataan positif, jawaban SS akan diberi poin $4, \mathrm{~S}$ akan diberi poin 3 , TS akan diberi poin 2, dan STS akan diberi poin
1. Sedangkan pada pernyataan negatif, jawaban SS akan diberi poin 1, S akan diberi poin 2, TS akan diberi poin 3, dan STS akan diberi poin 4 . Pemberian poin ini hanya untuk memudahkan dalam analisis data. Nilai hasil angket psychological self concept siswa dapat dilihat pada Tabel 2 berikut.

Tabel 2. Data psychological self concept siswa

\begin{tabular}{|l|c|c|c|c|c|c|}
\hline \multirow{2}{*}{ Subjek } & \multirow{2}{*}{ Nilai } & \multicolumn{4}{|c|}{ Pilihan Jawaban } & \multirow{2}{*}{ Rerata } \\
\cline { 3 - 6 } & & $\mathbf{4}$ & $\mathbf{3}$ & $\mathbf{2}$ & $\mathbf{1}$ & \\
\hline S-1 & 56 & 8 & 4 & 5 & 2 & $\mathbf{2 . 9 5}$ \\
\hline S-2 & 55 & 3 & 12 & 3 & 1 & $\mathbf{2 . 8 9}$ \\
\hline S-3 & 55 & 8 & 4 & 4 & 3 & $\mathbf{2 . 8 9}$ \\
\hline S-4 & 57 & 9 & 4 & 3 & 3 & $\mathbf{3 . 0 0}$ \\
\hline S-5 & 60 & 6 & 11 & 1 & 1 & $\mathbf{3 . 1 6}$ \\
\hline S-6 & 58 & 4 & 13 & 1 & 1 & $\mathbf{3 . 0 5}$ \\
\hline S-7 & 61 & 8 & 8 & 2 & 1 & $\mathbf{3 . 2 1}$ \\
\hline S-8 & 59 & 5 & 11 & 3 & 0 & $\mathbf{3 . 1 1}$ \\
\hline S-9 & 58 & 4 & 12 & 3 & 0 & $\mathbf{3 . 0 5}$ \\
\hline S-10 & 56 & 4 & 10 & 5 & 0 & $\mathbf{2 . 9 5}$ \\
\hline S-11 & 69 & 13 & 5 & 1 & 0 & $\mathbf{3 . 6 3}$ \\
\hline S-12 & 55 & 3 & 11 & 5 & 0 & $\mathbf{2 . 8 9}$ \\
\hline S-13 & 53 & 1 & 13 & 5 & 0 & $\mathbf{2 . 7 9}$ \\
\hline S-14 & 55 & 3 & 11 & 5 & 0 & $\mathbf{2 . 8 9}$ \\
\hline
\end{tabular}




\begin{tabular}{|c|c|c|c|c|c|c|}
\hline S-15 & 52 & 1 & 13 & 4 & 1 & 2.74 \\
\hline S-16 & 52 & 0 & 14 & 5 & 0 & 2.74 \\
\hline S-17 & 52 & 1 & 12 & 6 & 0 & 2.74 \\
\hline S-18 & 51 & 1 & 11 & 7 & 0 & 2.68 \\
\hline S-19 & 49 & 0 & 11 & 8 & 0 & 2.58 \\
\hline S-20 & 53 & 2 & 12 & 4 & 1 & 2.79 \\
\hline S-21 & 51 & 0 & 13 & 6 & 0 & 2.68 \\
\hline $\mathrm{S}-22$ & 53 & 1 & 13 & 5 & 0 & 2.79 \\
\hline $\mathrm{S}-23$ & 60 & 6 & 10 & 3 & 0 & 3.16 \\
\hline S-24 & 54 & 9 & 4 & 5 & 1 & 2.84 \\
\hline S-25 & 59 & 10 & 3 & 4 & 2 & 3.11 \\
\hline S-26 & 52 & 3 & 8 & 8 & 0 & 2.74 \\
\hline S-27 & 52 & 1 & 13 & 4 & 1 & 2.74 \\
\hline S-28 & 54 & 2 & 12 & 5 & 0 & 2.84 \\
\hline S-29 & 55 & 4 & 10 & 4 & 1 & 2.89 \\
\hline S-30 & 52 & 1 & 12 & 6 & 0 & 2.74 \\
\hline Rerata & 55.27 & & & & & \\
\hline Deviasi & 4.03 & & & & & \\
\hline
\end{tabular}

Data yang diperoleh dari angket pola asuh orang tua dan psychological self concept siswa berupa data berskala ordinal. Agar data angket ini dapat diolah dan dicari nilai korelasinya, maka data ordinal tersebut harus ditransformasikan menjadi data berskala interval. Transformasi data ordinal menjadi data interval dilakukan menggunakan metode yang dikenal dengan MSI (Methods of Successive Interval). Hasil transformasi data ordinal menjadi data interval dapat dilihat pada Tabel 3 berikut.

Tabel 3 Transformasi Data Ordinal menjadi Data Interval

\begin{tabular}{|c|c|c|c|c|c|}
\hline $\begin{array}{c}\text { Subjek } \\
\text { Orang Tua }\end{array}$ & Ordinal & Interval & $\begin{array}{c}\text { Subjek } \\
\text { Siswa }\end{array}$ & Ordinal & Interval \\
\hline S-1 & 54.00 & 54.38 & S-1 & 56.00 & 51.82 \\
\hline S-2 & 53.00 & 52.19 & S-2 & 55.00 & 49.34 \\
\hline S-3 & 54.00 & 54.38 & S-3 & 55.00 & 49.34 \\
\hline
\end{tabular}




\begin{tabular}{|c|c|c|c|c|c|}
\hline S-4 & 49.00 & 43.44 & S-4 & 57.00 & 54.30 \\
\hline S-5 & 51.00 & 47.81 & S-5 & 60.00 & 61.73 \\
\hline S-6 & 53.00 & 52.19 & S-6 & 58.00 & 56.78 \\
\hline S-7 & 52.00 & 50.00 & S-7 & 61.00 & 64.21 \\
\hline S-8 & 57.00 & 60.94 & S-8 & 59.00 & 59.26 \\
\hline S-9 & 55.00 & 56.56 & S-9 & 58.00 & 56.78 \\
\hline S-10 & 56.00 & 58.75 & S-10 & 56.00 & 51.82 \\
\hline S-11 & 51.00 & 47.81 & S-11 & 69.00 & 84.05 \\
\hline S-12 & 48.00 & 41.25 & S-12 & 55.00 & 49.34 \\
\hline S-13 & 50.00 & 45.62 & S-13 & 53.00 & 44.38 \\
\hline S-14 & 48.00 & 41.25 & S-14 & 55.00 & 49.34 \\
\hline S-15 & 53.00 & 52.19 & S-15 & 52.00 & 41.90 \\
\hline S-16 & 52.00 & 50.00 & S-16 & 52.00 & 41.90 \\
\hline S-17 & 37.00 & 17.19 & S-17 & 52.00 & 41.90 \\
\hline S-18 & 51.00 & 47.81 & S-18 & 51.00 & 39.42 \\
\hline S-19 & 47.00 & 39.06 & S-19 & 49.00 & 34.46 \\
\hline S-20 & 49.00 & 43.44 & S-20 & 53.00 & 44.38 \\
\hline S-21 & 52.00 & 50.00 & S-21 & 51.00 & 39.42 \\
\hline S-22 & 49.00 & 43.44 & S-22 & 53.00 & 44.38 \\
\hline S-23 & 59.00 & 65.31 & S-23 & 60.00 & 61.73 \\
\hline S-24 & 58.00 & 63.13 & S-24 & 54.00 & 46.86 \\
\hline S-25 & 59.00 & 65.31 & S-25 & 59.00 & 59.26 \\
\hline S-26 & 59.00 & 65.31 & S-26 & 52.00 & 41.90 \\
\hline S-27 & 51.00 & 47.81 & S-27 & 52.00 & 41.90 \\
\hline S-28 & 50.00 & 45.62 & S-28 & 54.00 & 46.86 \\
\hline S-29 & 56.00 & 58.75 & S-29 & 55.00 & 49.34 \\
\hline S-30 & 47.00 & 39.06 & S-30 & 52.00 & 41.90 \\
\hline
\end{tabular}


Selanjutnya data interval pola asuh orang tua dan psychological self concept siswa diolah menggunakan Software SPSS v.18 guna dicari nilai korelasi Pearson Product Moment-nya. Nilai korelasinya dapat dilihat pada Tabel 4.
Data Tabel 4 menunjukkan bahwa nilai korelasi $r_{\mathrm{ppm}}=0,301$ dengan interpretasi hubungan rendah, dan $P$-Value $=0,106$. Karena nilai $P$-Value $>0,01$, maka Terima $\mathrm{H}_{0}$ dan Tolak $\mathrm{H}_{1}$ yang berarti tidak terdapat hubungan antara pola asuh orang tua dengan psychological self concept siswa.

Tabel 4 Nilai Korelasi Pearson Product Moment

\begin{tabular}{|ll|r|r|}
\hline & Pola_Asuh & Self_Concept \\
\hline Pola_Asuh & $\begin{array}{l}\text { Pearson } \\
\text { Correlation } \\
\text { Sig. (2-tailed) }\end{array}$ & 1 & .301 \\
$\mathrm{~N}$ & 30 & .106 \\
& & 30 \\
\hline
\end{tabular}

\section{SIMPULAN}

Berdasarkan hasil pengolahan dan deskripsi data pada bab 4, maka terdapat beberapa kesimpulan yang dapat diambil. Adapun kesimpulan dari penelitian ini dapat diuraikan sebagai berikut.

1. Berdasarkan hasil uji korelasi Pearson Product Moment $\left(\mathrm{r}_{\mathrm{ppm}}\right)$ didapatkan nilai korelasi $\mathrm{r}=0,301$ dengan interpretasi hubungan yang rendah antara pola asuh orang tua dengan psychological self concept siswa. Sedangkan $P$-Value yang didapat $=0,106(P$ Value $>0,01)$ sehingga dapat disimpulkan bahwa tidak terdapat hubungan yang signifikan antara pola asuh orang tua dengan psychological self concept siswa.

2. Berdasarkan deskripsi data pada bab 4 subbab 4.5, semakin mempertegas bahwa tidak terdapat hubungan yang signifikan antara pola asuh orang tua dengan psychological self concept siswa, hal ini terbukti dari perbandingan nilai pola asuh orang tua dengan nilai psychological self concept siswa yang beragam. Meskipun terdapat orang tua yang memiliki pola asuh otoriter, tetapi psychological self concept anaknya tetap dalam interpretasi baik.

\section{DAFTAR PUSTAKA}

(2012). Pedoman Penulisan Karya Ilmiah. Universitas Pendidikan Indonesia. Bandung.

Akdon. (2008). Aplikasi Statistika dan Metode Penelitian untuk Administrasi dan Manajemen. Dewa Ruchi. Bandung Barat.

Alim, Melvi Lesmana. (2009). Kontribusi Pola Asuh Orang Tua dan Bimbingan Guru Terhadap Perilaku Sosial Anak pada Taman Kanak-kanak: Studi Analisis Deskriptif Pada Taman KanakKanak Di Kota PekanbaruRiau. S2 thesis, Universitas Pendidikan Indonesia. Bandung.

Beaty, Janice J. (1998). Observing Development of The Young Child. Prentice-Hall, Inc. New Jersey. 
Brianti. (2010). Perbedaan Penyesuaian

Sosial Pada Anak yang Menjalani

Sistem Pembelajaran Taman

Kanak-kanak Full Days dan

Reguler. [Online]. Tersedia:

http://eprints.uns.ac.id/ [9

Nopember 2015].

Desmita. (2008). Psikologi Perkembangan. PT. Remaja Rosdakarya. Bandung.

Desmita. (2012). Psikologi Perkembangan Peserta Didik. Bandung. Remaja Rosdakarya.

Kosim, Nandang. (2009). Kontribusi Pola Asuh Orang Tua dan Bimbingan Guru Terhadap Kecerdasan Emosional Anak Usia Dini : Studi Deskriptif Analitik pada Taman Kanak - Kanak Se-Kecamatan Pandeglang. S2 thesis, Universitas Pendidikan Indonesia. Bandung.

Marion, Marian. (1991). Guidance of Young Children. McMillan Publishing Company. New York.

Nutrisianty, Rima. (2014). Hubungan Antara Pola Asuh Orang Tua dengan Kecerdasan Emosional Anak Usia Dini : Penelitian Korelasional Terhadap Anak Kelompok $B$ di TK Pertiwi Kuningan. S1 thesis, Universitas Pendidikan Indonesia. Bandung.

Peterson, Candida. (1996). Looking Forward Through The Life Span. Developmental Psychology. $\quad 3^{\text {rd }}$ Edition. Prentice-Hall, Inc. Sydney.

Putri, Ariyani. (2014). Hubungan Antara Pola Asuh Orang Tua dengan Kecerdasan Spiritual Anak Raudhatul Athfal : Penelitian Korelasional pada Anak Kelompok $B$ di RA Miftahul Huda Kec.Tarogong Kaler Kab.Garut Tahun Pelajaran 2014-2015. S1 thesis, Universitas Pendidikan Indonesia. Bandung.

Riduwan. (2010). Belajar Mudah Penelitian, Untuk Guru-Karyawan dan
Peneliti Pemula. Alfabeta. Bandung.

Santrock, John W. (2002). Life-Span Development. Perkembangan Masa Hidup. Edisi Kelima. Jilid 1. Erlangga. Jakarta.

Schmidt, John J. (2010). The Elementary/Middle School Counselor's Survival Guide. United States of America.

Silviyani, Nova. (2015). Pengaruh Model Pembelajaran Berbasis Proyek Terhadap Kemampuan Representasi Matematis dan Psychological Self Concept Siswa. Skripsi. Universitas Swadaya Gunung Jati. Cirebon.

Sit. (2012). Peningkatan Kemampuan Sosial Anak Usia Dini dengan Metode Bermain Peran. [Online]. Tersedia: http://jurnaldikbud.net/index.php/jp nk/69 [9 Nopember 2015].

Sujiono, Yuliani Nurani. (2011). Konsep Dasar Pendidikan Anak Usia Dini. PT. Indeks. Jakarta.

Sund, Robert B. (1976). Piaget for Educators, A Multimedia Program. Bell \& Howell Company. Ohio.

Tomlinson, Heather Biggar., Hyson, Marilou. (2012).

Developmentally Appropiate Practice. Washington DC.

Yus. (2011). Penilaian Perkembangan Belajar Anak Taman Kanak-kanak. Jakarta: Kencana.

Yusuf LN., Syamsu. (2007). Buku Materi Pokok, Pedagogik Pendidikan Dasar. Sekolah Pasca Sarjana. Universitas Pendidikan Indonesia. Bandung.

Yusuf LN., Syamsu. (2006). Psikologi Perkembangan Anak \& Remaja. PT. Remaja Rosdakarya. Bandung.

Yusuf LN dan Nurikhsan. (2011). Teori Kepribadian. Bandung: PT. Remaja Rosdakarya. 
